\title{
A Novel Application of EIS for Quantitative Coating Quality Assessment During Neutral Salt Spray Testing of High-Durability Coatings
}

\author{
Marina Mrđa Lalić ${ }^{1,2^{*}}$ and Sanja Martinez ${ }^{1}$ \\ ${ }^{1}$ University of Zagreb, Faculty of Chemical Engineering and Technology, Department of Electrochemistry, \\ Savska cesta 16/I, 10000 Zagreb, Croatia \\ ${ }^{2}$ Koncar Power Transformers Ltd, A Joint Venture of Siemens and Koncar d.d., \\ Josipa Mokrovica 12, 10000 Zagreb, Croatia \\ *Corresponding author: E-mail: marina.mrda@siemens.com \\ Phone: +385992951416
}

Received: 03-07-2019

\begin{abstract}
The aim of the study was to exemplify the benefits of using electrochemical impedance spectroscopy (EIS) for quantification of coating quality during accelerated corrosion testing before the appearance of visual changes on the surface of the coating. The study included an innovative application of the commercial flexible gel electrodes in a two-electrode setup for following the impedance of the two high-durability offshore coating systems exposed to $1440 \mathrm{~h}$ of neutral salt spray (NSS) according to EN ISO 9227. The results were compared to those of the EIS measurements during $8000 \mathrm{~h}$ long exposure to a liquid electrolyte in a press-on cell according to the established EN ISO 16773 method. Complementary methods of differential scanning calorimetry, Fourier transform infrared spectroscopy and thermogravimetric analysis have been used for surface, interface and depth profiling of coating characteristics that were commented with respect to the EIS results.

The technique was applied on high-durability coatings Zn (R) + EP + EP or PUR intended for the protection in the coastal and offshore areas corresponding to C5- (H) and CX corrosivity categories in accordance with EN ISO 12944. EIS has been found to give sound quantitative results for coating impedance and a good estimation of long term coating behaviour within the first $100 \mathrm{~h}$ of accelerated exposure. It can be considered a promising tool for the early detection of coating damage during weathering tests.
\end{abstract}

Keywords: Durability of coatings; EIS; salt spray chamber; organic coatings degradation

\section{Introduction}

At present, epoxy and polyurethane coatings are the predominant types of coatings used in the offshore industry. Since offshore construction coatings face outdoor exposure continuously throughout their service life, which includes high relative humidity, rain, a saline corrosive atmosphere and high UV radiation, their lifetime is shortened. The expected lifetime for an offshore construction is 20 years or more and high-performance coatings are required for this application to avoid excessive and expensive maintenance operations and the loss of revenue. ${ }^{1}$ An anticorrosive coating system usually consists of multiple layers of different coatings with different properties and purpose. A typical anticorrosive system for highly corrosive marine environments usually consists of a primer, one or several intermediate coats, and a top coat. The function of the primer is to protect the substrate from corrosion and to ensure good adhesion to the substrate. The function of the intermediate coat is to build up the thickness of the coating system and impede the transport of aggressive species to the substrate surface. The topcoat is exposed to the external environment and must provide the surface with the required colour and gloss.

The overall system is characterized by high electrical resistance and low capacitance which may quickly and easily be quantitatively measured, especially, after the development of advanced EIS instruments having: pA current measurement range, high input impedance up to $1 \mathrm{~T} \Omega$, variable gain amplifiers, variable filters input front-ends and a floating ground. ${ }^{2,3}$ Over the last few decades, electrochemical methods have found widespread use for characterization of anticorrosive coatings and have been commonly employed to assess the performance and durability 
of anticorrosive coatings in the laboratory. ${ }^{4}$ By making periodic EIS measurements during the exposure to the corrosive environment, the level of coating damage can be estimated. EIS is a non-destructive measurement that may be used to track the condition of a coated metal sample as it changes. ${ }^{5}$ Equivalent circuit models using passive electrical engineering and physics circuit elements have commonly been used to help interpret EIS studies of coating systems. Data analysis procedures need to use non-linear, complex least squares fitting algorithm program of these equivalent electrical circuits (EEC) models to the EIS data. ${ }^{6}$ EEC is commonly used to interpret EIS studies of coating systems, but in some cases, calculated data from EEC models are not completely comparable with experimental data, moreover finding an exact matched model is quite difficult. The performance of the coating is evaluated according to the magnitude of the parameters in the equivalent circuit and their changes with exposure time. ${ }^{7-10}$ Other approaches such as minimum phase angle and its frequency, frequency breakpoint, the impedance at low frequency, the changing rate of impedance and phase angle at high frequencies have been used by some researchers to avoid these problems. ${ }^{11}$ It is accepted among researchers that the initial step in the degradation process is the loss of dielectric properties of the polymer resulting from water ingress into the coating film. The relation between the initial and final coating capacitance may be an appropriate parameter by which to rank coating lifetime. ${ }^{12}$ Also, low frequency coating resistance is taken as an indicator of coating quality. ${ }^{7-9}$ Excellent coatings have resistance values $10^{8}-10^{12} \Omega \mathrm{cm}^{2}$ and poor corrosion protection properties are exhibited when resistance intensity drops below $10^{5} \Omega \mathrm{cm}^{2} .^{13}$ The appearance of coating defects is observed when coating impedance value falls below $10^{6} \Omega \mathrm{cm}^{2}{ }^{21}{ }^{14} \mathrm{Im}-$ pedance greater or equal to $10^{9} \Omega$ corresponds to excellent protecting properties of coatings which provide almost purely capacitive behaviour over long exposure periods. ${ }^{15}$ The described EIS model may be applied to various industrial coating types and thicknesses providing a universal tool for coating quality and protective ability compari$\operatorname{son}^{1-18}$.

The coatings industry regularly applies spectroscopic $^{16-21}$ and thermal analysis ${ }^{18,22,23}$ methods that allow the assessment of coating characteristics before and after their exposure to a wide variety of service conditions. These methods are complementary to EIS because unlike EIS, they do not generate quantitative data that relates to barrier properties of a coating on a metal substrate but rather data related to the coating surface chemistry and bulk polymer thermal behaviour.

Nowadays, the most commonly employed method to assess offshore (CX corrosivity class) coating systems quality relies on long-term cyclic exposure in a climatic chamber until visible signs of coating degradation appear. Moreover, the 2017 edition of EN ISO 12944-6 standard redefines coating durability classes and suggests the appli- cation of cyclic accelerated corrosion tests for $\mathrm{C} 4$ of high and very high durability and C5 coating systems of high and very high durability. Due to the long duration of 4200 $h$ and a high cost of such tests, the change could incur significant expense to coating manufacturers. The advantage of EIS is that it can indicate changes in the coating long before any visible damage commences, ${ }^{5,24}$ hence it is of great technical importance to investigate quantification of the coating quality by EIS with the prospects of early detection of coating degradation during accelerated testing as well as during exposure to service conditions.

In the present study, two coating systems consisting of zinc epoxy primer and two epoxy coats one with, and the other without the polyurethane topcoat, have been investigated. The focus of the investigation was on early detection of coating degradation during exposure to neutral salt spray (NSS) done according to the EN ISO 9227 standard and corresponding to the requirement for $\mathrm{C} 5$ and $\mathrm{CX}$ categories as defined by ISO 12944-6. EIS has been measured periodically during the NSS test by shortly stopping the exposure to salt mist and performing measurements with the flexible gel electrodes which enabled capturing of the momentary coating state. ${ }^{2,3,25-27}$ For comparison, measurements have also been done by EIS according to EN ISO 16773 standard and by FTIR, DSC and TGA methods.

\section{Experimental}

\section{1. Material and Preparation}

Carbon steel sheets with dimensions of $(100 \times 150 \times$ $10 \mathrm{~mm}$ ) were used as a metallic substrate. The samples were sand-blasted to Sa 2.5 (according to EN ISO 8501-1) and the surface was cleaned from visible oil and dirt. Two coating system denoted as System A and System B have been applied to the carbon steel panels by the air spraying technique. The application has been done according to the instructions of the manufacturer, and therefore it may be assumed that the application process has no consequences on the observed behaviour of the coatings. Specifications of the selected two-component coating systems are shown in Table 1. The main component in basecoat is zinc dust (50-75\%) in addition bisphenol A epoxy resin, xylene, solvent naphtha. The intermediate coat is high solids epoxy polyamide adduct cured contain bisphenol A epoxy resin (10-25\%). Topcoat cured with aliphatic isocyanate and contains zinc phosphate. The minimum number of layers and the nominal film thickness of each coating is determined according to the type of coating materials, the corrosivity category and the required durability. System A corresponded to the System No. C5.7, for corrosivity category $\mathrm{C} 5$, with a lifetime of 15 to 25 years and a nominal dry film thickness (NDFT) $>260 \mu \mathrm{m}$ according to ISO 129445. System B corresponded to the System No. C5.8, for the extreme corrosivity category CX (Offshore) with a lifetime of range more than 25 years and an NDFT $>320 \mu \mathrm{m}$. The 
Table 1. Specifications for the investigated commercial coating systems

\begin{tabular}{|c|c|c|c|c|c|c|}
\hline Coating system & $\begin{array}{c}\text { Number of } \\
\text { layers }\end{array}$ & Coating type & $\begin{array}{l}\text { Cumulative thickness } \\
\qquad(\mu \mathrm{m})\end{array}$ & Base polymer & $\begin{array}{l}\text { VOC } \\
(\mathrm{g} / \mathrm{L})\end{array}$ & $\begin{array}{c}\text { Solvents } \\
\text { by weight }(\%)\end{array}$ \\
\hline \multirow[t]{2}{*}{ System A } & 2 & Basecoat & 270 & Zinc rich epoxy & 307 & 44 \\
\hline & & Intermediate coat & & Epoxy (polyamide) & 216 & 50 \\
\hline \multirow{3}{*}{ System B } & 3 & Basecoat & 460 & Zinc rich epoxy & 307 & 44 \\
\hline & & Intermediate coat & & Epoxy (polyamide) & 216 & 50 \\
\hline & & Topcoat & & Acrylic polyurethane & 336 & 36 \\
\hline
\end{tabular}

coatings consisted of two components, a resin and a hardener component.

\section{2. Instrumentation}

\section{2. 1. Electrochemical Impedance Spectroscopy (EIS) Measurements}

EIS measurements started two months after the application of the coating which allowed for proper drying. EIS measurements were carried out at the open circuit potential (OCP) with a DC potential amplitude of $10 \mathrm{mV}$ in the frequency range of $10^{4} \mathrm{~Hz}$ to $10^{-2} \mathrm{~Hz}$. The coated steel panels were put into a Faraday cage which eliminated external electromagnetic noise during the EIS testing. The three-electrode cell constructed according to EN ISO 16773 consists of an inert cylinder, which is attached to the coating surface and filled with electrolyte. A stainless-steel mesh serves as the counter electrode (CE) and the metal substrate is the working electrode (WE). The counter electrode has a circular hole in the middle where the calomel reference electrode (SCE) is protruding. ${ }^{28} \mathrm{~A}$ two gel-electrode system consists of a pair low-cost, commercial polymeric gel electrodes placed in parallel at the surface of the metal. ${ }^{29-31}$ One electrode is connected to the working electrode input of the potentiostat and the other to the reference and counter electrode input. Schematic setup of the measurement cells is shown in Figure 1. Details of the Re-

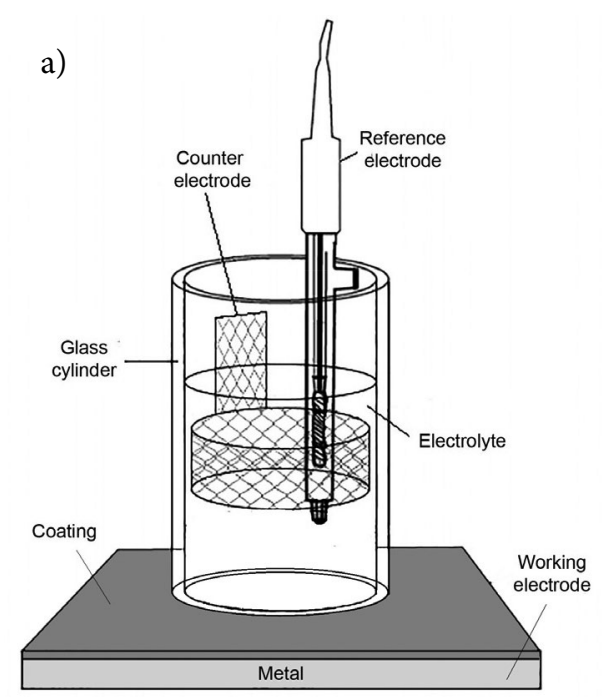

corr CQC customized instrumental setup that has been developed in our laboratory were presented previously. ${ }^{32}$ Calibration of the setup has been done according to EN ISO $16773-3$, on a high-impedance dummy cell mimicking the coating. The EIS data is analysed based on the low frequency impedance at $0.1 \mathrm{~Hz}$ and the shape of the Bode plot curves. The performance of the coating is evaluated according to the magnitude of impedance and its change with the exposure time. ${ }^{33,8-9}$

For the three-electrode system the exposed coated sample area was $28,27 \mathrm{~cm}^{2}$ and for the two-electrode system, the area was $32 \mathrm{~cm}^{2}$. Coating degradation was induced in two ways: by exposure to liquid 3.5\% sodium chloride $(\mathrm{NaCl})$ at room temperature $\left(21^{\circ} \mathrm{C}\right)$ for $8000 \mathrm{~h}$ in a test conducted according to EN ISO 16772 and by exposure to $\mathrm{NSS}$ of $5 \% \mathrm{NaCl}$ at $35^{\circ} \mathrm{C}$ according to EN ISO 9227 for $1440 \mathrm{~h}$. In both cases measurements were carried out in time intervals that enabled capturing of the significant changes in the extent of coating degradation.

\section{2. 2. Fourier Transform-Infrared Spectroscopy (FTIR) Measurements}

Chemical changes were measured with Fourier Transform Infrared (ATR-FTIR) ${ }^{34}$ spectroscopy method before and after exposure of the samples to external conditions. PerkinElmer spectrometer Spectrum One, USA con-

Figure 1. a) a three-electrode cell constructed according to EN ISO 16733 and b) a two-electrode setup. ${ }^{32}$ 
nected to a computer program interface for capturing the sample spectrum has been used. Each spectrum was an average of ten scans recorded with a resolution of $4 \mathrm{~cm}^{-1}$. Attenuated Total Reflection (ATR-FTIR) method applied directly on coated samples has a limitation of the measurement range from 4000 to $650 \mathrm{~cm}^{-1}$ and part of the spectrum between 650 and $200 \mathrm{~cm}^{-1}$ is lost. Therefore, FTIR was also measured in transmission mode in a spectral range from 4000 to $450 \mathrm{~cm}^{-1}$. This required preparation of samples in the form of pellets in accordance with the standard ASTM E1252:200735. $3 \mathrm{mg}$ of scraped powder from the surface of each coated sample was mixed into 350 $\mathrm{mg}$ of spectroscopically pure $\mathrm{KBr}$. The mixture was milled in agate mortar until we obtained a fine and very homogeneous mixture. Samples with $\mathrm{KBr}$ were then hydraulically pressed into a $13 \mathrm{~mm}$ stainless steel die and resulting pellets further subjected to FTIR measurement.

\section{2. 3. Thermogravimetric Analysis (TGA) Measurements}

Thermal stability of each coating system was investigated using Q500 (TA instruments) with auto sampler controlled by TA Universal Analysis software. The epoxy (polyamide) and acrylic polyurethane films were applied on a plastic foil with an applicator in range $0.16-0.25 \mathrm{~mm}$ and dried at room temperature for $72 \mathrm{~h}$. The experiments were performed in nitrogen atmosphere (flow of 40-60 ml $\mathrm{min}^{-1}$ ) at a heating rate of $10{ }^{\circ} \mathrm{C} \mathrm{min}^{-1}$ over the temperature range of $1000^{\circ} \mathrm{C}$.

\section{2. 4. Differential Scanning Calorimetry (DSC)}

DSC is a thermal analysis technique commonly used to determine parameters such as glass transition temperatures (Tg), melting points ( $\mathrm{mg}$ ) and heat capacities of materials. ${ }^{9} \mathrm{~T}_{\mathrm{g}}$ of samples was measured by DSC before and after exposure to the salt spray chamber. The measurements were carried out on Mettler Toledo DSC 823 controller at a scan rate of $20^{\circ} \mathrm{C} \mathrm{min}{ }^{-1}$ over the temperature range from 0 to $90^{\circ} \mathrm{C}$ in two heating cycles under a nitrogen atmosphere with a constant flow of $60 \mathrm{~mL} \mathrm{~min}{ }^{-1}$. All samples $(10 \mathrm{mg} \pm 3 \mathrm{mg}$ ) were weighed and sealed in a hermetic aluminium pan with lids. The measurement was conducted according to the EN ISO 11357.

\section{Results and Discussion}

\section{1. EIS Results}

Measurements of impedance obtained by the two flexible electrodes setup are shown in Figure 2 for systems $\mathrm{A}$ and $\mathrm{B}$. Bode plots of the intact coating show its excellent protective action, i.e. the low-frequency impedance greater than $1.0 \times 10^{11} \Omega$. Measurements of impedance obtained by the three electrodes setup in a cell filled with
3.5\% $\mathrm{NaCl}$ are shown in Figure 3. The initial measurements were done after $2.5 \mathrm{~h}$ of exposure and the measured Bode curves show the low-frequency impedance value is already below $1.0 \times 10^{10} \Omega$, which is significantly lower than the impedance of the intact coating.

Low-frequency impedance read at $0.1 \mathrm{~Hz}$ and normalized by the electrode area is shown as a function of exposure time for coating systems A and B in Figure 3, for the NSS and $3.5 \% \mathrm{NaCl}$ tests. It is evident that the low-frequency impedance value in all cases drops sharply during the first $100 \mathrm{~h}$ of exposure. For system $\mathrm{A}$, in both tests, the final impedance falls to the values around $10^{7} \Omega \mathrm{cm}^{2}$, although initially being by almost an order of magnitude lower for the NSS test. This would imply that more severe corrosive conditions are attained during the NSS test than during immersion in $3.5 \% \mathrm{NaCl}$ when it comes to epoxy coating. Deflorian et al. compared the results obtained by EIS and salt spray, have visually observed that the samples were nearly intact after more than three months of immersion but had many blisters on the coating after only a few weeks of salt spray exposure. ${ }^{36}$

System A is made up of zinc rich basecoat and an epoxy topcoat applied at a thickness of $270 \mu \mathrm{m}$. Hence, the drop in low-frequency impedance is larger for system A than for the System B that has an extra layer of polyurethane and a total thickness of $460 \mu \mathrm{m}$.

For system $B$, in both tests, the final impedance falls to values around $10^{10} \Omega \mathrm{cm}^{2}$, although initially being by about half an order of magnitude higher for the NSS test. This would imply that more severe corrosive conditions are attained during the $3.5 \% \mathrm{NaCl}$ immersion test than during the NSS test when it comes to polyurethane coating. This is in concordance with the well-known, superior performance of epoxy coatings over the polyurethane coatings under immersion conditions. ${ }^{14}$

The oscillatory behaviour of impedance during the EIS tests has been observed previously and might be explained by pore blockage by corrosion products and the random formation of macroscopic perforations in the coating. ${ }^{37}$ Although the authors refer to the observed oscillations as a drawback of the EIS method and its failure to give reproducible results, it should be noted that the result in fact shows the ability of EIS to authentically reflect the true state of the coating. The oscillatory effect is more pronounced for the lower quality coating and for the NSS exposure. Nevertheless, the average impedance of each system can readily be deduced from the plots and rating of the coating quality can be done with reasonable confidence. According to the literature criteria based on the impedance at $0.1 \mathrm{~Hz},{ }^{38}$ system $\mathrm{B}$ may be rated as excellent and system $A$ as fair.

Besides the quantitative rating of the coating quality, much can also be deduced from the shape of the Bode plots. ${ }^{39}$ To simplify conclusions and explicate the potential for widespread use of the suggested method, the shape of the Bode curves is explained. 
It is widely accepted that the EIS spectrum of an efficient protective coating can be presented by a simple model of capacitance in a parallel to a resistance. ${ }^{40}$ High-frequency impedance response for the intact coating is a straight line with the unit negative slope and the phase angle close to $-90^{\circ}$, as seen from Figure 2 a) and Figure 3 a). Such a dependency is characteristic of almost pure capacitive behaviour. It is well known that, during exposure to an electrolyte, the coating first shows deviation from the capacitive behaviour. ${ }^{41}$ An increase of the phase angle slope from -1 to higher values in the high-frequency region signifies frequency dispersion that requires the substitution of pure capacitance for the CPE element in the coating equivalent circuit. CPE probably reflects water ingress within the polymer matrix causing a variety of RC combinations in parallel forming a distributed equivalent circuit. ${ }^{42}$

Corrosion initiation at the substrate causes a second time constant appearance at frequencies below $1 \mathrm{~Hz} .{ }^{40}$ The low frequency response depends on the rate of the charge transfer reaction at the base of polymer defects and below the delaminated coating. The nested low-frequency equivalent circuit is comprised of a double layer capacitance and a polarization resistance. When diffusion effects in the coating pores are present, the Warburg element is added in series with the charge transfer resistance.

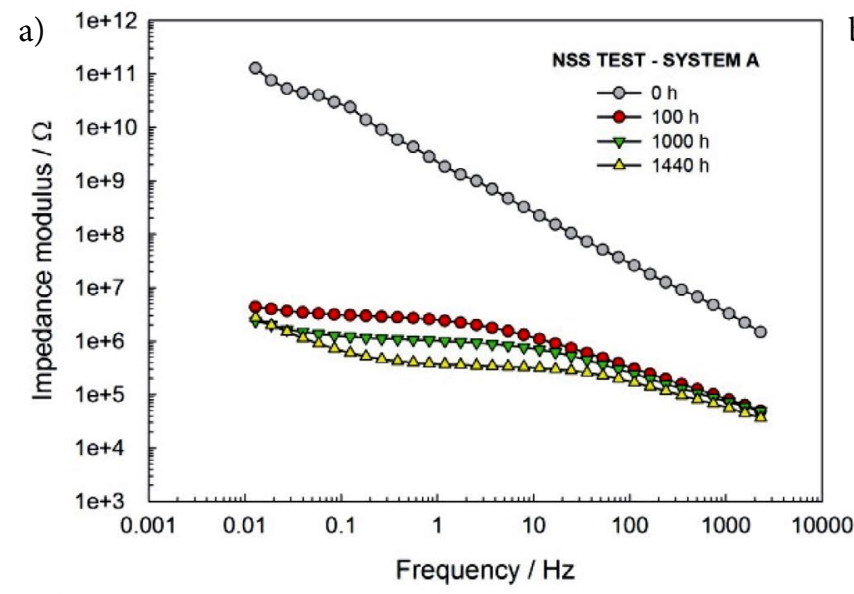

c)

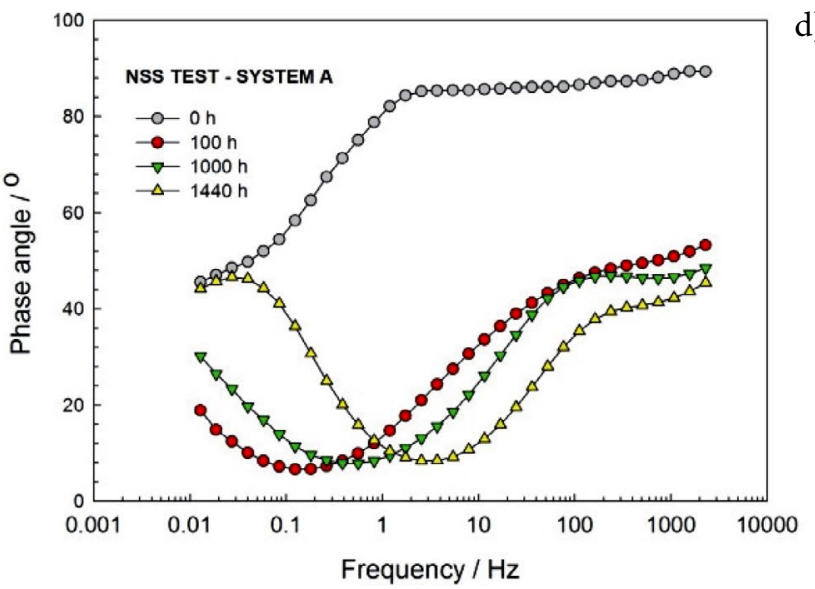

In the case of System A, the two time constants are clearly visible even for the $100 \mathrm{~h}$ of exposure to NSS. In the case of system B, a mild indication of the low-frequency time constant that almost completely overlaps with the high-frequency one is observed. Narrowing of the capacitive region, depression of the phase angle and deflection of the impedance slope from -1 are more pronounced for the system A.

For the $3.5 \% \mathrm{NaCl}$ immersion tests, system A shows poorly resolved low-frequency time constant only for the longest time of exposure confirming the previously mentioned good protective properties of the epoxy coating under immersion conditions. System B again shows overlapping time constants but retains higher phase angle values than in the NSS experiment.

Photographs of both systems prior to exposure and after the NSS and 3.5\% NaCl tests are shown in Figure 5. No apparent coating defects are visible. System B shows mild browning of the surface colour after the NSS test that may indicate substrate corrosion and corresponds to the pronounced low-frequency time constant observed for this coating. A conclusion about the comparable protective ability of the coatings might be drawn from the visual assessment of the coated specimen after the NSS and 3.5\% $\mathrm{NaCl}$ tests. It is now obvious why the coating tests for high
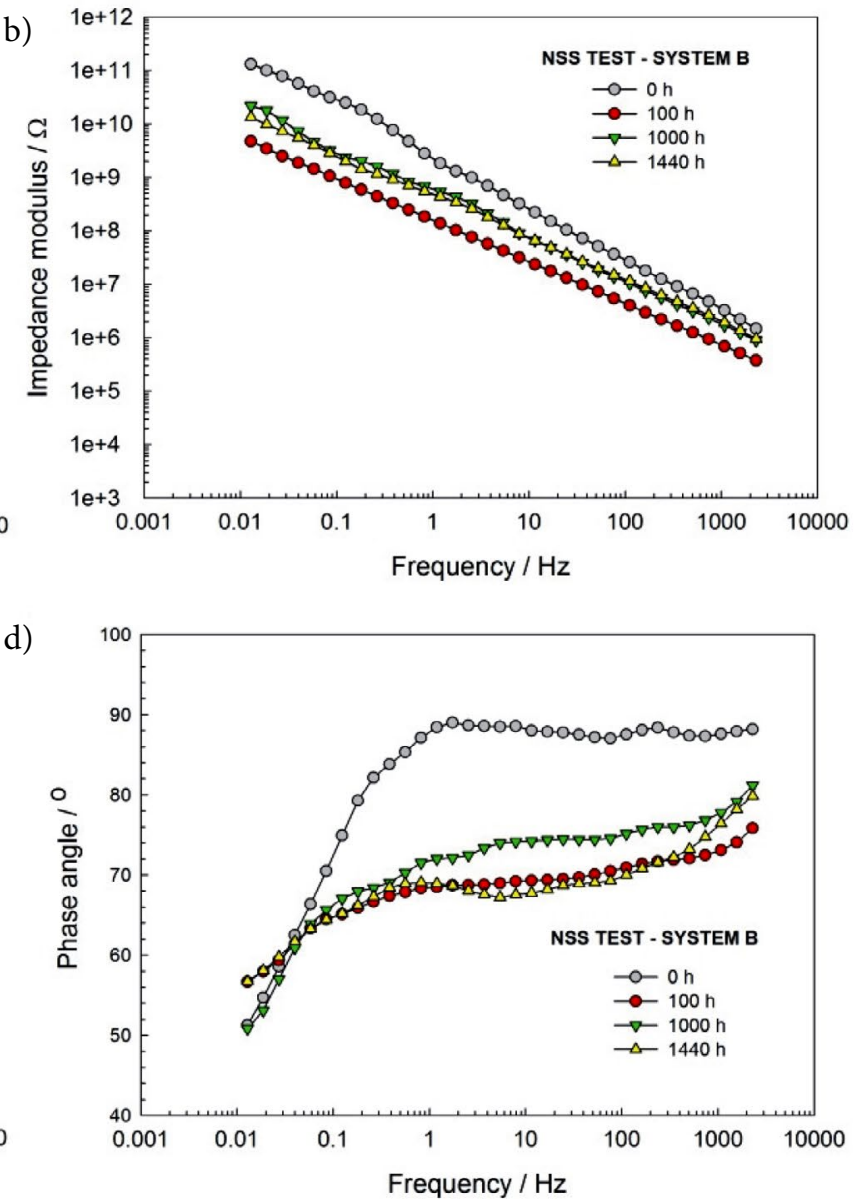

Figure 2. Bode plots of a) and c) system A samples and b) and d) of system B samples exposed to NSS. 

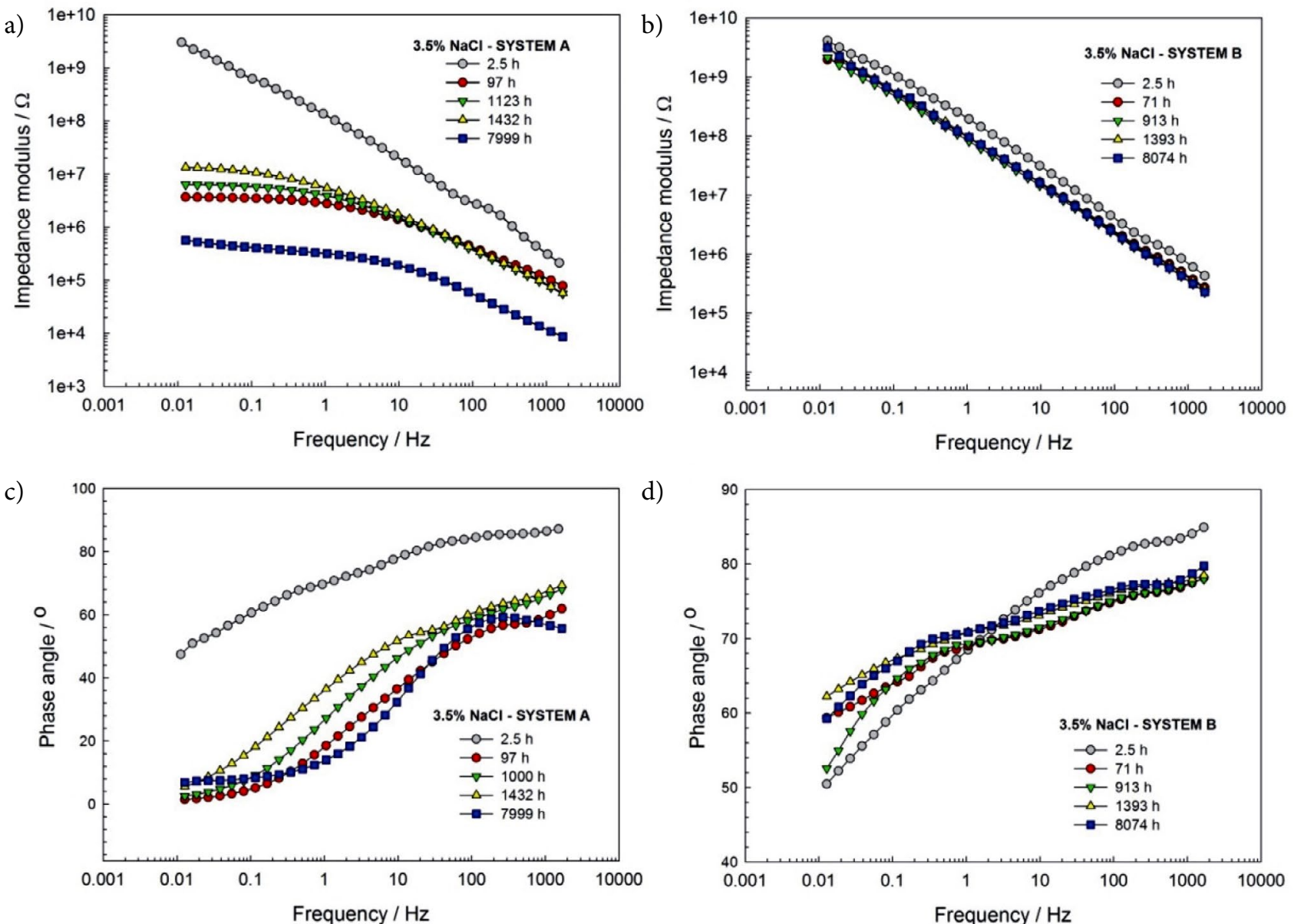

Figure 3. Bode plots of a) and c) system A samples and b) and d) of system B samples exposed to $3.5 \% \mathrm{NaCl}$.

and very high durability coating systems given in the new edition of the EN ISO 12944-6 standard suggest gradual transfer from the NSS test to the considerably longer and more expensive cyclic exposure tests that would probably inflict visible difference among the coating systems intended for heavy-duty service conditions.

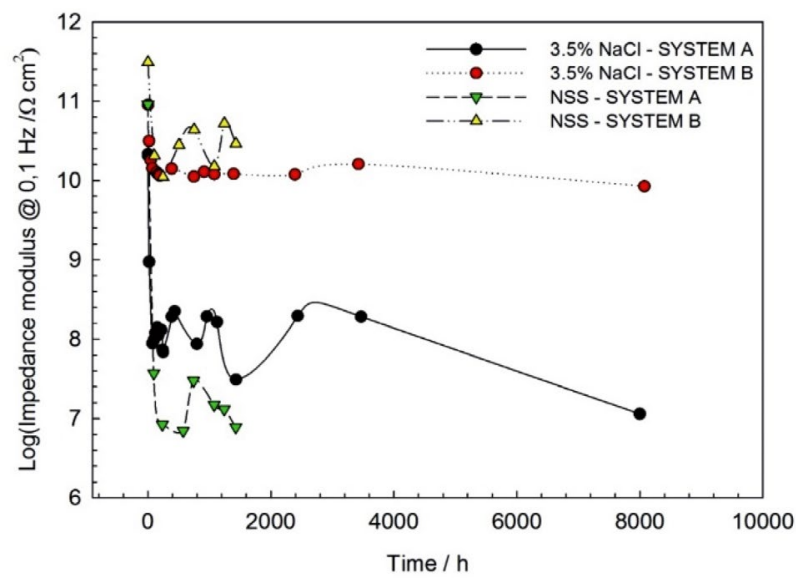

Figure 4. Low-frequency impedance read at $0.1 \mathrm{~Hz}$ as a function of exposure time for coating systems $\mathrm{A}$ and $\mathrm{B}$ during exposure to $3.5 \%$ $\mathrm{NaCl}$ and NSS.

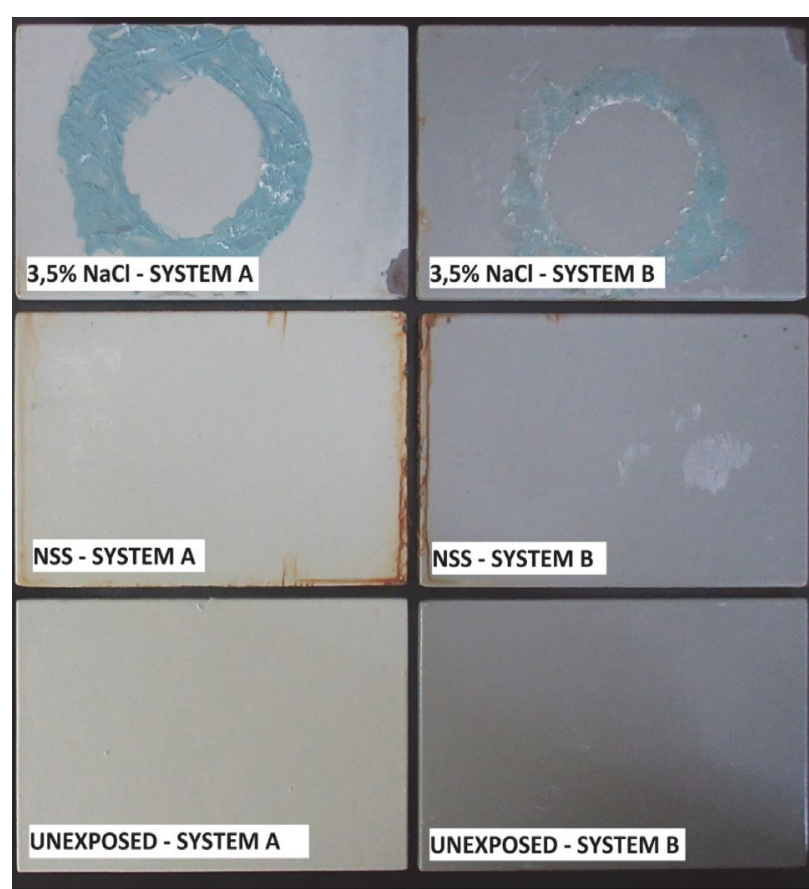

Figure 5. Photographs of specimens coating systems $A$ and $B$ before exposure, after exposure NSS and after exposure $3.5 \mathrm{wt} \% \mathrm{NaCl}$ solution. 


\section{2. Characterization of Coating System by FTIR}

Figures 6 and 7 show the spectra for systems A and B, respectively, before and after exposure to NSS and 3.5\% $\mathrm{NaCl}$ tests. Spectra were obtained in two ways, by the ATR FTIR method and from $\mathrm{KBr}$ pellets containing scraped powder form the sample surface. It can be concluded that all the spectra shown in Figure 6 show characteristic bands of epoxy resin bisphenol A around $827 \mathrm{~cm}^{-1} ; 1245 \mathrm{~cm}^{-1}$; $1509 \mathrm{~cm}^{-1} .^{43}$ The spectra in Figure 7 correspond to acrylic polyurethane resin. ${ }^{44}$

a)

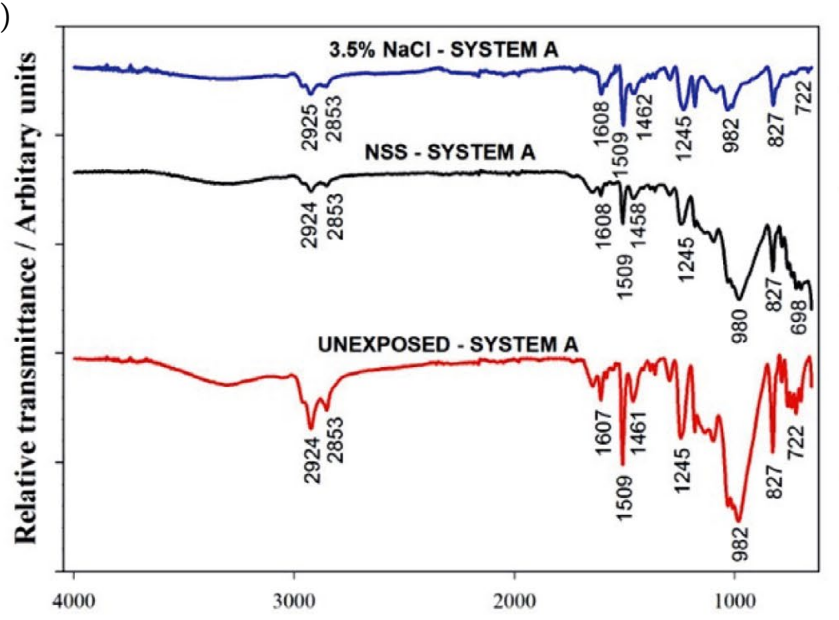

Wavenumber $/ \mathrm{cm}^{-1}$ tigated organic coatings do not change significantly after exposure which demonstrates a lack of degradation. No bands corresponding to corrosion products are observed. New absorption bands did not appear, except in the case of the system $\mathrm{B}$ exposed to $3.5 \% \mathrm{NaCl}$ which shows a new band at $2345 \mathrm{~cm}^{-1}$ corresponding to $\mathrm{CO}_{2} \cdot{ }^{45}$

It has been observed that when chemical bonds in the polyurethane coating are fractured under UV irradiation free radicals are generated, releasing $\mathrm{CO}_{2} \cdot{ }^{45}$ Since the sample has not been exposed to UV irradiation, the appearance of $\mathrm{CO}_{2}$ is probably due to the reaction of unreacted isocyanate with the water from the salt cabinet. The

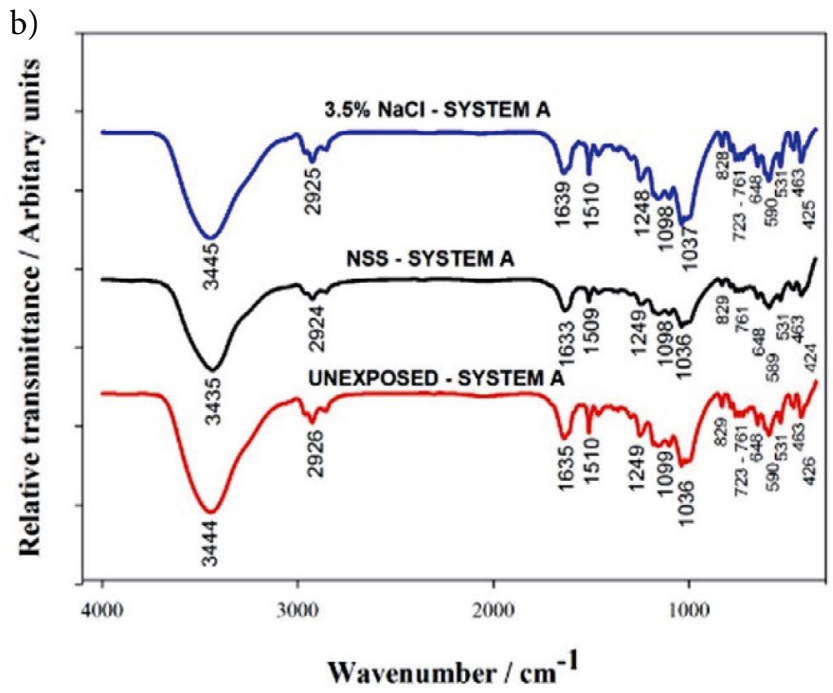

Figure 6. Spectra for system A before and after exposure to NSS and 3.5\% $\mathrm{NaCl}$ tests obtained a) by the ATR FTIR method and b) from KBr pellets containing the scraped powder form the sample surface.

No clear conclusion about the difference in the state of the coatings before and after exposure can be deduced from the fingerprint region in Figures 6 and 7. The locations, the width and the intensity of the bands of the inves-

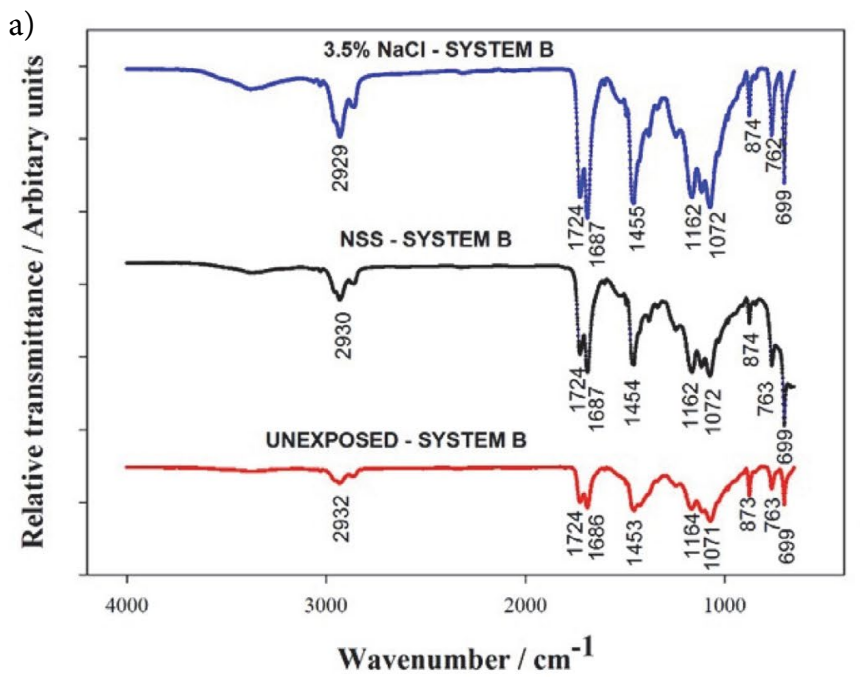

fact that $\mathrm{CO}_{2}$ is observed only in the scraped powder indicates its residence within the polymer matrix.

S. Rashtchi et al. state that the spectral region between $3400 \mathrm{~cm}^{-1}$ and $3700 \mathrm{~cm}^{-1}$ is the best indicator of the

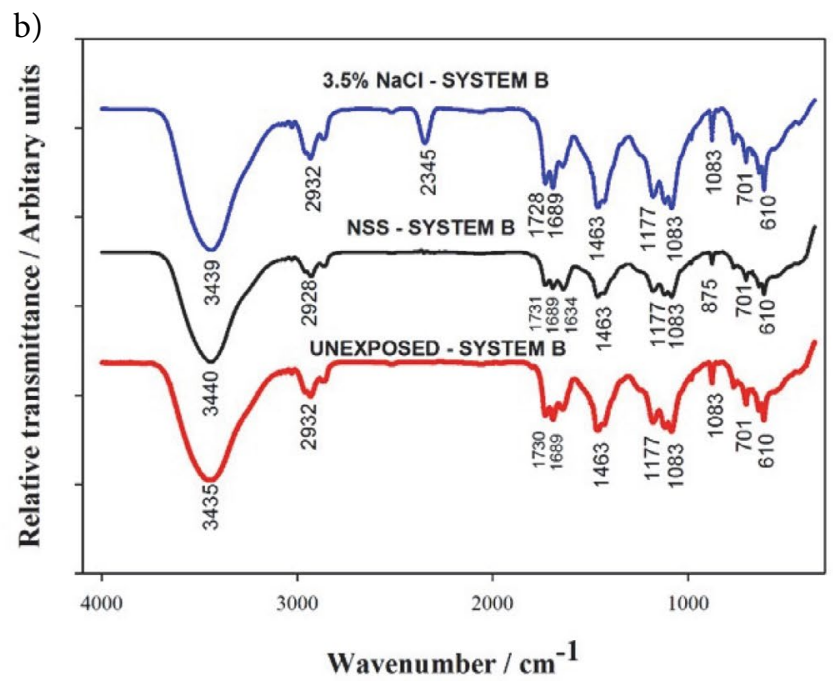

Figure 7. Spectra for system B before and after exposure to NSS and 3.5\% $\mathrm{NaCl}$ tests obtained a) by the ATR FTIR method and b) from KBr pellets containing the scraped powder form the sample surface. 
moisture presence. ${ }^{46}$ It should be noted that after the NSS and $3.5 \% \mathrm{NaCl}$ experiments the painted samples were left for 3 months at room temperature and humidity, which allowed them to dry. ${ }^{47}$ This could account for the almost complete lack of bands ascribed to water in ATR spectra.

Conversely, $\mathrm{KBr}$ pellets' show a well resolved band at $3440 \mathrm{~cm}^{-1}$ as well as the less resolved bands between 1634 and $1639 \mathrm{~cm}^{-1}$ for both coating systems. These bands denote the presence of water and indicate $(-\mathrm{OH})$ stretching and scissors vibrations of the bonded water molecules, respectively. This water is probably due to the improper drying of $\mathrm{KBr}$ pellets.

\section{3. Characterization of Coating System by DSC and TGA}

Glass transition temperature for coating systems A and B before and after exposure to NSS in test and to $3.5 \%$ $\mathrm{NaCl}$ test is presented in Figure 8. Two glass transition temperatures denoted as $\mathrm{T}_{\text {ghi }}$ and $\mathrm{T}_{\text {glo }}$ have been measured for all the coatings indicating a biphasic system that could be related to the homogeneity of water distribution in the polymer. ${ }^{48}$

For both systems decrease in $\mathrm{T}_{\text {ghi }}$ values after exposure to NSS is $\leq 4{ }^{\circ} \mathrm{C}$ and may be considered insignificant as it barely exceeds the measurements uncertainty of DSC that is taken as equal to $3^{\circ} \mathrm{C}$. $\mathrm{T}_{\text {ghi }}$ values after exposure to $3.5 \% \mathrm{NaCl}$, as well as all the $\mathrm{T}_{\text {glo }}$ values, are increased by up to $12{ }^{\circ} \mathrm{C}$.

$\mathrm{T}_{\mathrm{g}}$ decrease for both systems is probably related to the water residing in the polymer free volume. ${ }^{48}$ The increase in $T_{g}$ values may be explained by the water ingress into the polymer network and secondary cross-linking through the formation of multiple hydrogen bonds between water and polymer. ${ }^{49}$ DSC experiments were done on the same samples as FTIR. Apparently, after the 3 months drying period, the final state of the samples indicates irreversible changes in the form of multiple hydrogen bonded water residing in highly cross-linked zones of the polymer. ${ }^{50}$

According to Del Grosso the water in the intact coating can be detected with TGA at $110^{\circ} \mathrm{C} .{ }^{51}$ TGA curves of the intact epoxy and polyurethane coatings are shown in Figure $8 \mathrm{~b}$. Weight losses of $1.62 \%$ for epoxy (polyamide) and $1.30 \%$, for acrylic polyurethane, corresponding to the water content were recorded when the temperature reached $110^{\circ} \mathrm{C}$.

Full degradation occurred beyond $900^{\circ} \mathrm{C}$ leaving the residues of various weight loss percentages at the end of the TGA curve presented in Table 2. These are in good agreement with the declared percentage of solids by weight for the two coatings. TGA experiments showed two stages of weight loss for epoxy (polyamide) and three stages for acrylic polyurethane. An abrupt weight loss in coating systems was observed at high temperatures from approximately 300 to $500{ }^{\circ} \mathrm{C}$.

Table 2. Residual weight loss percentage of coating systems by thermogravimetric analysis

\begin{tabular}{ll}
\hline Coating system & $\begin{array}{l}\text { Residue at } 900{ }^{\circ} \mathrm{C} \\
\text { (\% by weight) }\end{array}$ \\
\hline epoxy (polyamide) & 50,11 \\
acrylic polyurethane & 34,29 \\
\hline
\end{tabular}

\section{Conclusions}

It has been demonstrated by this investigation that the EIS method gives a possibility of quantification of coating degradation and estimation of its long-term performance from the first $100 \mathrm{~h}$ of exposure to NSS in the EN
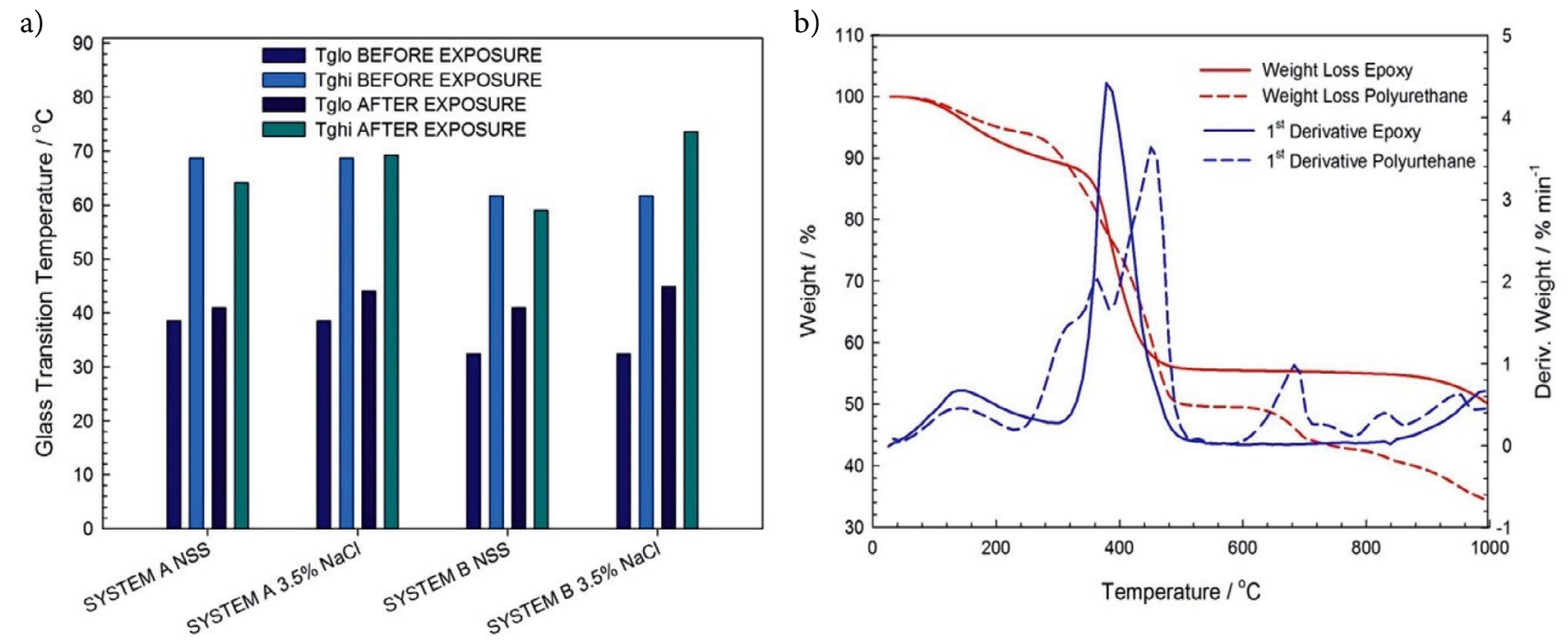

Figure 8. a) glass transition temperatures for coating systems A and B before and after exposure to NSS and to $3.5 \% \mathrm{NaCl}$ and b) TGA curves of intact epoxy (polyamide) epoxy and acrylic polyurethane coatings. 
ISO 9227 test and to the $3.5 \% \mathrm{NaCl}$ in EN ISO 16773 test. Contrarily, prolongation of the tests to $1440 \mathrm{~h}$ in the case of NSS exposure and to $8000 \mathrm{~h}$ in the case of $3.5 \% \mathrm{NaCl}$ exposure has produced no visible degradation signs on the coatings.

FTIR, DSC and TGA results preferentially gave information about the water absorbed within the coating that resides within the polymer free volume and within the polymer network. DSC method indicates irreversible changes related to the water ingress into the polymer network. Besides the water ingress, further irreversible changes related to the degradation of barrier properties of the coatings due to the corrosion at the bottom of the coating pores and under delaminated coating are DSC method indicates irreversible changes related to the water ingress into the polymer network. Besides the water ingress, further irreversible changes related to the degradation of barrier properties of the coatings due to the corrosion at the bottom of the coating pores and under delaminated coating are detectible by EIS.

Finally, both, quantitation of the coating behaviour during long-term accelerated weathering exposures by the impedance modulus at $0.1 \mathrm{~Hz}$ and the analysis of the shape of the Bode plots can give early information about the coating quality. Widespread use of this method could reveal patterns common to the frequently used high-performance coatings, strengthen the conclusions of this study and considerably shorten the time and cost of coating quality assurance.

\section{Acknowledgements}

The authors would like to thank professor dr. sc. Mirela Leskovac from the Department of Surface Engineering of Polymer Materials, Faculty of Chemical Engineering and Technology to helped in handling of the instruments for DSC and TGA methods and Ivana Šoić for help with FTIR method.

\section{References}

1. H. L. Dedeurwearder, Protecting Offshore Wind Farm Towers, JPCL, 2015, https://www.paintsquare.com (assessed: March 04, 2019)

2. S. Grassini, S. Corbellini, M. Parvis, E. Angelini, F. Zucchi, J. Int. Meas. Confed., 2018, 114, 508-514.

DOI:10.1016/j.measurement.2016.07.014

3. B. Ramirez Barat, E. Cano, Chem. Electro. Chem., 2018, 5, 2698-2716. DOI:10.1002/celc.201800844

4. P. A. Sørensen, S. Kiil, K. Dam-Johansen, C. E. Weinell, J. Coat. Technol. Res., 2009, 6,135-176.

DOI:10.1007/s11998-008-9144-2

5. D. Loveday, P. Peterson, B. Rodgers, Evaluation of Organic Coatings with Electrochemical Impedance Spectroscopy Part 2: Application of EIS to Coatings, http://www.consultrsr.net/ files/jct/JCT200502.pdf (assessed: February 28, 2019)
6. B. R. Hinderliter, S. G. Croll, D. E. Tallman, Q. Su, G. P. Bierwagen, Electrochem. Acta, 2006, 51, 4505-4515.

DOI:10.1016/j.electacta.2005.12.047

7. A. A. Hashem, J. A. Carew, A. Hasan, Surf. Coat. Int., 1999, 82, 26-30. DOI:10.1007/BF02693014

8. C. H. Tsai, F. Mansfeld, Corros. Sci., 1993, 49, 726-737. DOI:10.5006/1.3316106

9. C. Kong, Material Mind., 2015, 9, 27-28. DOI:10.1038/scientificamericanmind1116-28

10. S. Skale, V. Doleček, M. Slemnik, Prog. Org. Coat., 2008, 62, 387-392. DOI:10.1016/j.porgcoat.2008.02.003

11. E. Akbarinezhad, M. Bahremandi, H. R. Faridi, F. Razaei, Corros. Sci., 2009, 51, 356-364.

DOI:10.1016/j.corsci.2008.10.029

12. L. De Rosa, T. Monetta, D. B. Mitton, F. Bellucci, J. Electrochem. Soc., 1998, 145, 3830-3838. DOI:10.1149/1.1838881

13. J. Neshati, M. Faradi, Surf. Eng., 2009, 20, 299-303. DOI:10.1179/026708404225016418

14. S, Shreepathi, A. K. Gui, S. M. Naik, M. R. Vattipalli, Jour. Coat. Techn. \& Rese., 2011, 8, 191-200.

DOI:10.1007/s11998-010-9299-5

15. B. J. Merten, A. Skaja, D. Tordonato, D. Little, Re- evaluating Electrochemical Impedance Spectroscopy (EIS) for the Field Inspector's Tolbox: A Frst Approach https://www.usbr.gov/ research/projects/researcher.cfm?id=2334 (assessed: February.28, 2019)

16. J. T. Zhang, J. M. Hu, J. Q. Zhang, C. N. Cao, Prog. Org. Coat., 2004, 51, 145-151. DOI:10.1016/j.porgcoat.2004.08.001

17. X. F. Yang, C. Vang, D. E. Tallman, G. P. Bierwagen, S. G. Croll, S. Rohlik, Polym. Degra. Stab., 2001, 74, 341-351.

DOI:10.1016/S0141-3910(01)00166-5

18. F. Deflorian, L. Fedrizzi, S. Rossi, Corros. Sci., 1998, 54, 98 605. DOI: $10.5006 / 1.3287635$

19. E. Almeida, M. Balmayore, T. Santos, Prog. Org. Coat., 2002, 44, 233-242. DOI:10.1016/S0300-9440(02)00056-5

20. M. R. Costa, M. T. Santos, T C. Diamantino, Corros. Prot. Mater., 2011, 30, 57-64.

21. J. Li, L. Ecco, Fedel, Ermini, G. Delmas, J. Pan, Prog. Org. Coat., 2015, 87, 179-188. DOI:10.1016/j.porgcoat.2015.06.003

22. J. Li, C. S. Jeffcoate, G. P. Bierwagen, D. J. Mills, D. E. Tallma, Corros. Sci., 1998, 54, 763-771. DOI:10.5006/1.3284797

23. M. F. M. Nazeri, M. S. M. Suan, M. N. Masri, N. Alias, M. W. A. Rashid, Y. Alias, A. A. Mohamad, Int. J. Electrochem., 2012, 7, 9633-9642.

24. J. Mlntyre, H. Pham, Prg. Org. Coat., 1996, 27, 201-207. DOI:10.1016/S0022-4375(96)90001-8

25. S. Grassini, Corros. Conser. Cult. Her Met. Art., 2013, 347367. DOI:10.1533/9781782421573.4.347

26. E. Anglini, S. Grassini, M. Parvis, F. Zucchi, Surf. Interface Anal., 2012, 44, 942-946. DOI:10.1002/sia.3842

27. S. Corbellini, M. Parvis, S. Grassini, IEEE Transac. Instr. \& Meas., 2012,61,1193-1200. DOI:10.1109/TIM.2011.2175816

28. T. Bos, "Prediction of coating durability - Early detection using electrochemical methods, Delft University, The Netherlands, PhD Thesis, 2008.

29. S. Jamali, Y. Zhao, Z. Gao, H. Li, A. C. Hee, J. Int. Eng. Chem., 
2016, 43, 36-43. DOI:10.1016/j.jiec.2016.07.045

30. B. Ramirez Barat, E. Cano, P. Letardi, Sens. Actuators B., 2016, 43, 36-43. DOI:10.1016/j.snb.2018.01.180

31. Y. Kuo, Y. Lee, Y. L. Lee, Jour. Inter. Measu. Confe., 2018, 124, 303-308. DOI:10.1016/j.measurement.2018.04.041

32. S. Martinez, Conference Corrosion and Surface Treatment in Industry, Viglas, Slovakia, 2019.

33. A. A. Hashem, J. A. Carew, A. Hasan, Surf. Coat. Int., 1999, 82, 26-30. DOI:10.1007/BF02693014

34. J. Coates, Encyclopedia of Analytial Chemistry: Application, Theory and Instrumentation. Interpretation of Infrared Spectra A Practical Approach, Newtown, USA, 2006.

DOI:10.1002/9780470027318.a5606

35. "ASTM Standard E1252: General Techniques for Obtaining Infrared Spectra for Qualitative Analysis, ASTM International, 2007.

36. F. Deflorian, S. Rossi, L. Fedrizzi, J. Coat. Technol., 2000, 72, 81-87. DOI:10.1007/BF02698001

37. M. Del Grosso Destreri, J. Vogelsang, L. Fedrizzi, F. Deflorian, Prog. Org. Coat., 1999, 37, 69-81.

DOI:10.1016/S0300-9440(99)00056-9

38. L. Gray, B. Drader, M. O’Donoghue, R.Garret, J. Garret, R. Graham, V. Datta, Corrosion NACE, 2003, 03382.

39. A. Alizadeh Razin, B. Ramezanzadeh, H. Yari, Prog. Org. Coat., 2016, 92, 95-109. DOI:10.1016/j.porgcoat.2015.11.023

40. F. Mansfeld, J. Appl. Electrochem., 1994, 25, 187-202. DOI:10.1007/BF00262955
41. M. Kendig, J. Scully, Corrosion, 1990, 46, 22-29. DOI:10.5006/1.3585061

42. G. M. Ferra, E. M. P. van Westing, J. H. W. de Wit, Corrosion Sci., 1994, 36, 957-977. DOI:10.1016/0010-938X(94)90197-X

43. N. Tudorachi, F. Mustata, Arab. J. Chem., 2017. In Press, DOI:10.1016/j.arabjc.2017.07.008

44. F. Lu, B. Song, P. He, Z. Wang, J. Wang, RSC Adv., 2017, 7, 13742-13748. DOI:10.1039/C6RA26341K

45. Y. Zhang, A spectroscopic study of the degradation of polyurethane coil coatings, PhD Thesis, Queen Mary Univeristy of London, 2012.

46. S. Rashtchi, P. D. Ruiz, R. Wildman, I. Ashcroft, SPIE Solar Energy and Technology, San Diego, California, United States, 2012. DOI:10.1117/12.928959

47. S. G. Croll, Prog. Org. Coat., 2018, 124, 41-48. DOI:10.1016/j.porgcoat.2018.07.027

48. M. Y. M. Chiang, M. Fernandez-Garcia, J. Appl. Polym. Sci., 2003, 89, 1436-1444. DOI:10.1002/app.11576

49. N. Fredj, S. Cohendoz, X. Feaugas, S. Touzain, Prog. Org. Coat., 2010, 69, 82-91. DOI:10.1016/j.porgcoat.2010.05.009

50. F. Deflorian, L. Fedrizzi, S. Rossi, P.L. Bonora, Electrochim. Acta, 1999, 44, 4243-4249.

DOI:10.1016/S0013-4686(99)00139-5

51. M. Del Grosso Destreri, J. Vogelsang, L. Fedrizzi, F. Deflorian, Prog. Org. Coat., 1999, 37, 57-67.

DOI:10.1016/S0300-9440(99)00056-9

\section{Povzetek}

Namen študije je bil prikazati prednosti uporabe elektrokemijske impedančne spektroskopije (EIS) za kvantifikacijo kakovosti premaza pri pospešenem korozijskem testiranju pred pojavom vizualnih sprememb na površini premaza. Študija je vključevala inovativno uporabo komercialnih fleksibilnih elektrod na osnovi gela za spremljanje impedance dveh visoko obstojnih premaznih sistemov, ki se uporabljajo v morski vodi. Vzorce smo 1440 ur testirali v slani komori v skladu z EN ISO 9227 (NSS test). Rezultate smo primerjali z meritvami EIS med 8000-urno izpostavljenostjo tekočemu elektrolitu v preskusni celici po uveljavljeni metodi EN ISO 16773. Za površinsko, vmesno in globinsko profiliranje premaznih lastnosti materiala smo poleg EIS uporabili še dodatne metode: diferenčno dinamično kalorimetrija (DSC), infrardečo spektroskopijo (FT-IR) in termogravimetrično analizo (TGA).

Metodo smo preučevali na visoko obstojnih premazih Zn (R) + EP + EP ali PUR, namenjenih za zaščito na obalnih in morskih območjih, ki ustrezajo kategorijam C5- (H) in CX korozivnosti v skladu z EN ISO 12944. Z EIS lahko dobimo dobre kvantitativne rezultate in tudi dobro oceno dolgoročnega obnašanja premaza v prvih 100 urah pospešene izpostavljenosti. Metoda EIS bi bila lahko primerna za zgodnje odkrivanje poškodb premazov.

Except when otherwise noted, articles in this journal are published under the terms and conditions of the Creative Commons Attribution 4.0 International License 